DOI: https://doi.org/10.24297/jal.v11i.8551

\title{
An Empirical Study on the Relationship Between Language Proficiency and Economic Income of Chinese and Vietnamese Border Residents: A Case Study of Dongxing City, Guangxi Province
}

\author{
Bian Chenglin, Liu Jinlin, Yang Liuyan, Bian Zhiyao
}

Guangxi University for Nationalities, Nanning, Guangxi, 530006;

Academy of Marxism, Chinese Academy of Social Science, Beijing, 102488;

Cultural Communication College, Guangxi University of Finance and Economics, Nanning, Guangxi, 530002;

College of Film, Television \& Media, Guangxi Arts University, Nanning, Guangxi, 530007

103227135@qq.com. liujinlin@vip.126.com clbian@163.com. joycezhang2018@sina.com

An Introduction to the Author:

Bian Chenglin, male, Secretary of the Party Committee of Guangxi University for Nationalities, a Ph.D., Professor, main research fields: Linguistics and Applied Linguistics, Linguistic Economics

Liu Jinlin, male, Director of Social Sciences Division of Guangxi University for Nationalities, a Ph.D., Professor of Academy of Marxism, Chinese Academy of Social Sciences, main research fields: Linguistic Economics

Yang Liuyan, female, lecturer of Cultural Communication College, Guangxi University of Finance and Economics, Guangxi, Nanning, 530002.

This paper is the result of "The Research on the Mechanism of Language Serving County Economic Development", a project of the Guangxi Education Department. It also receives financial support from the construction of the first-class discipline-Ethnology at Guangxi Higher Educational Institutes.

\begin{abstract}
:
Based on the full sample survey of border residents in Dongxing City, Guangxi, this paper uses language economics theory and data analysis methods to analyze the relationship between language proficiency and income of border residents in Dongxing City, Guangxi. The conclusions of the study include: multilingual ability can enhance residents' self-employment ability, obtain more employment opportunities and stable income sources, and have a positive correlation with their annual income. Putonghua popularization is an effective measure to promote poverty alleviation in border areas; Government departments should optimize and improve local industrial policies and promote the promotion and protection of traditional cultures of ethnic minorities while giving full play to the positive economic and social benefits of Putonghua popularization and cultivating new economic drivers.
\end{abstract}

Key words: Language Proficiency; Targeted Poverty-Alleviation; Income 


\section{Introduction}

Both domestic and international theoretical and empirical research results show that language, as human capital, is an important tool for thinking, cognition and communication. Investment in language skills is conducive to improving personal income and social status. As a trading system and communication medium, promoting a common language is a necessary move to enhance the communication among people of all nationalities, promote economic and trade cooperation among countries in the world, and to expand the level of open cooperation. Located in the southwestern border of China and bordering Vietnam, Guangxi is the only province in China that is connected with the ASEAN by both land and sea. In the border line of more than 1,000 kilometers in length, there are eight border counties (cities, districts), therefore, it has an important strategic position in deepening open cooperation with the ASEAN and in maintaining national security and stability of the southwestern border. At the same time, Guangxi is the autonomous region with the largest population of ethnic minorities in China, as well as the old revolutionary land, ethnic minority area and frontier area. There are 29 poverty-stricken counties at the national level and 20 at the international level. Therefore, Guangxi is one of the key areas for targeted poverty-alleviation work and one of the main battlefields for the country to fight against poverty. However, due to its location in the mountains, traffic congestion, long-term isolation from the outside world, the development of infrastructure and social undertakings lags behind. And the lack of educational resources has increasingly become one of the constraints for targeted poverty-alleviation in these areas, because it produces a low level of education in most poor households in the border mountainous areas of Guangxi where people suffer from poor language foundation and language barriers, for they have little opportunity to learn Chinese, to know Chinese characters, and to understand Putonghua. Poverty alleviation should first improve people's educational level which is in turn based on language learning, and targeted poverty-alleviation with language promotion has become the prerequisite and guarantee for the successful implementation of this basic national strategy in these areas.

This paper conducts extensive research on the language conditions of border residents in Guangxi. Based on the perspective of linguistic economics, it deeply analyzing the influence of language skills acquisition on local family income, labor mobility, migrant working, and business engagement. Then puts forward some suggestions on promoting the overall poverty alleviation in this area from the perspective of language policies such as popularization of Putonghua. This research is of positive significance for the deep integration of the Guangxi border area into the national "The Belt and Road Initiative", the completion of its poverty alleviation task, and for its construction of a well-off society in an all-round way.

\section{Research Design}

\subsection{Research Subjects}

There are 8 counties (cities and districts) in the border area of Guangxi, including Dongxing City, Fangcheng District in Fangchenggang; Ningming County, Pingxiang City, Longzhou County, Daxin County in Chongzuo; Jingxi City and Napo County in Baise. The research object of this paper is Dongxing City, Fangchenggang. Located in the southern part of Guangxi Zhuang Autonomous Region, Dongxing is an intersection city along the border, the river and the coast, where the land borderline begins and the coastline ends. It is the only port city between China and ASEAN across the land and the sea. It is also the heartland of China-ASEAN Free Trade Area, "Two Corridors and One Circle", "Pan-North Cooperation" and "One Axis and Two Wings". And it is separated from the largest and most open special economic zone at Móng Cái port in northern Vietnam by only 
a river. The land borderline of Dongxing City lasts 39 kilometers, including 8 communities and 18 natural villages, with a total of 14,863 households and 69,820 people $^{1}$. All residents on the border are the subject of this survey. Therefore, this survey is a full sample survey. The contents of the survey included name, gender, age, language ability, occupation, average annual income, local characteristic industries, local ethnic culture, minority language use and ethnic cultural heritage, etc. Taking into account the main purpose of the research group is to explore the resident's linguistic competence in communication, the focus is on examining the resident's language skills such as listening, speaking, reading, writing and translating. Therefore, the definition of linguistic competence is mainly based on the viewpoint of American sociolinguist Dell Hymes rather than Chomsky². Hymes believes that "linguistic competence is just a kind of ability to deal with things, including linguistic knowledge, techniques and skills of using grammar (linguistic knowledge). Among them, linguistic knowledge is the source, not an intrinsic, abstract cognitive state of governance structure. Grammatical knowledge is the key issue, as it is one part of communicative competence". Correspondingly, when making the language proficiency scale for the residents, we mainly reference the Chinese Proficiency Test (HSK), Business Chinese Test (BCT) ${ }^{3}$, CET-SET $^{4}$ and other descriptions on Chinese, Business Chinese and English proficiency levels, as well as J. C. Alderson's (2014) ${ }^{5}$ Classification criteria of language proficiency. From the concept of language as a communicative tool, resident's language ability (including Putonghua) can be divided into four levels: proficient, competent, barely competent

1 Considering that preschool children under the age of 6 have not reached the age of enrollment and education, and have no employability, they are not included in this survey.

2 In 1965, American philosopher and linguist Chomsky put forward the concept of "linguistic competence", which holds that linguistic competence is a state of knowledge far more abstract than language itself, a system of principles, a system of knowledge, but not a kind of ability to deal with things, or even the ability to organize and understand sentences. In his view, linguistic competence refers to the grammatical rules internalized by an ideal native speaker.

3 Based on language communicative competence, Confucius Institute Headquarters (Hanban) classifies HSK into four grades: basic, elementary, medium and advanced. Business Chinese Test (BCT) divides business Chinese into five levels: level 1, not yet able to use Chinese in business activities to communicate; Level 2, able to use Chinese in business activities for basic communication; Level 3, capable to use Chinese effectively in business activities to communicate; level 4, able to use Chinese proficiently in business activities to communicate; Level 5, able to use Chinese freely and appropriately in business activities. See: National Chinese Language Proficiency Examination Department of Hanban. Chinese Language Proficiency Grade Standards and Grammar Level Syllabus [M]. Higher Education Press, 1996 edition. communication on familiar subjects in English is basically not difficult; oral communication on familiar subjects in English is difficult, but it does not affect communication; simple communication on familiar subjects in English is achievable; not yet able to do oral communication in English.

5 J. C. Alderson (2014) believes that the language proficiency scale can be classified into 3 categories: user-oriented, assessororiented and constructor-oriented, and the corresponding language competence description varies. User-oriented scales mainly describe the typical language performance of language learners at all levels, depicting what communicative tasks residents can accomplish with language, and focus on the comprehensive description of language competence of residents. See: J. C. Alderson. Issues in language testing revisited. Language Assessment Quarterly. 2014, 11 (02). PP. 125-128. 
and incompetent ${ }^{6}$. Being proficient means that speakers can use one or more languages quite skillfully to communicate in their life; being competent indicates that speakers can speak one or more languages relatively effective to communicate in daily life; barely competent means that speakers can understand basic vocabulary in daily life and are able to communicate basically in a certain language or more languages; being incompetent refers that speakers are unable to communicate in a certain language or more languages in their lives. The occupations of the residents can be classified into seven categories: migrant workers, farmers, businessmen, civil servants, students, other occupations and unemployment ${ }^{7}$. According to their income, the average annual income is divided into four grades: $0-20,000$ yuan, 20,001-36,000 yuan, 36,001-72,000 yuan and 72,001 yuan or more.

\subsection{Research Methods and Contents}

The investigation combines mainly fieldwork with questionnaire research. On the basis of door-to-door interviews and informal discussions and exchanges, structured interviews (standardized interviews, closedended interviews), semi-structured interviews and unstructured interviews (open-ended interviews) which are conducted among all the residents of Dongxing border area, it is aimed to collect comprehensive, authentic and reliable first-hand data on the language proficiency, average annual income, educational background and occupations of the residents in the region. Questionnaire questions include two parts: subjective and objective questions. The former enquires about their suggestions on the development of local characteristic industries, the necessity of strengthening minority culture protection ${ }^{8}$, the influence of Putonghua popularization on the

6

From the perspective of psychometrics, the preparation of psychometric scales generally includes setting reference points, measurement units and the total length of the scale (Zhang Houcan, 1988; Brennan, 2006). Considering that this survey mainly considers the resident's language communicative competence, as well as the accuracy and operability requirements of the scale, this research group divides the resident's language proficiency into four grades: proficient, competent, barely competent and incompetent. Among them, the first level corresponds to grade 4-5 of BCT and grade A-A + of CET-SET; the second level corresponds to grade 3 of BCT and grade $\mathrm{B}-\mathrm{B}+$ of CET-SET; the third level is consistent with grade 2 of BCT and grade C-C + of CET-SET; and the last level corresponds to grade 1 of BCT and grade D of CET-SET.

$7 \quad$ Other occupations refer to the fact that residents do not have fixed jobs, but they use their leisure time to do odd jobs to obtain certain income, such as engaging in border trade, renting houses, building houses in rural areas and so on. The frontier trade forms of Dongxing include mutual fair trade among the inhabitants of border areas, frontier petty trade and ordinary trade. There are 2 corresponding trade channels: the Dongxing Port, the main import and export channels of ordinary trade and frontier petty trade; and the Dongxing Mutual Trade Zone for Frontier People, the main import and export channels of mutual fair trade. In recent years, the Trade Zone has issued a "tax-free policy for goods under 8000 yuan", that is, in this Trade Zone, every border people can buy goods under 8000 yuan a day without paying taxes. Due to the limited living needs of the border people, the amount of 8000 yuan is basically not exceeded. Therefore, some border people begin to use border people's certificates to buy goods for the non-border people who need them, and earn about 30 yuan a day from them which is called "passer-by money". At the same time, some border people bring commodities into Dongxing processing enterprises to earn certain income through mutual trade. It is estimated that 3000 border people provide services to the mutual-market commodity processing enterprises every year, which strongly promotes the development of such enterprises in Dongxing City.

$8 \quad$ Fixed geographic and social networks will lead to the solidification of living habits (including language use) and thinking patterns, and exclude the entry of external factors (Wang Chunhui, 2018b). In order to analyze deeply the correlation among resident's language ability, local business and investment promotion and the development of specialty industries, as well as the impact of Putonghua promotion on the protection and inheritance of local minority languages and cultures, the survey team has expanded the scale of investigation to include the development status of local specialty industries and the protection and inheritance of minority cultures. 
use of minority languages, etc. The latter contains the name, gender, age, language proficiency, occupation, and average annual income of the respondents, etc.

\subsection{Research Organization and Implementation}

Considering that the research involves mainly economics, linguistics and sociology, it is reasonable to form a survey team of 17 people by absorbing experts from these three disciplines. Among them, 2 experts and professors, as well as 3 lecturers and 8 master candidates, specialize in linguistics and dialect research for a long time; and $1 \mathrm{PhD}$ professor, together with 1 lecturer and 2 master candidates focus on economics disciplines such as institutional economics and regional economics. This team conducted an eight-day survey in Dongxing City from February 26 to March 5, 2018. In the pre-survey stage, preliminary preparation was done on February 26,2018 , including the printing of questionnaires, the contact with government departments and village committees, and the formulation of the survey plan; During the formal investigation stage from February 27 to March 3, 2018, the team first divided their work according to the research tasks and then conducted door-todoor interviews and informal discussions with the residents of the villages and townships under their respective responsibilities to obtain first-hand information. In the field study on March 4, 2018, the team selected deliberately some towns, villages and townships for field research to collect data on the protection and inheritance of minority characteristic culture, the urban construction and targeted poverty-alleviation progress in small towns with characteristics. On March 5, 2018, the statistical stage of this survey, team members collated, counted, analyzed and studied systematically the questionnaire and collected materials, and wrote the survey report. In the whole process, for school-age children, migrant workers, businessmen, school students and other residents who were not at home at the time of the investigation, the survey team obtained their relevant information mainly through interviews with their parents, siblings and other relatives or village committee cadres.

\section{An Analysis of Language Proficiency of Border Residents in Dongxi City}

\subsection{Multilingual Proficiency Analysis}

The languages and dialects spoken by Dongxing border residents are Putonghua, Vernacular (Cantonese), Gin language, Hakka, Zhuang and Vietnamese. The survey results show that there are 15,672 monolingual people, including 15,646 Cantonese speakers, 26 Hakka speakers, 40851 bilingual people, 13,227 trilingual people and 70 quadrilingal people (see Figure 1 for details).

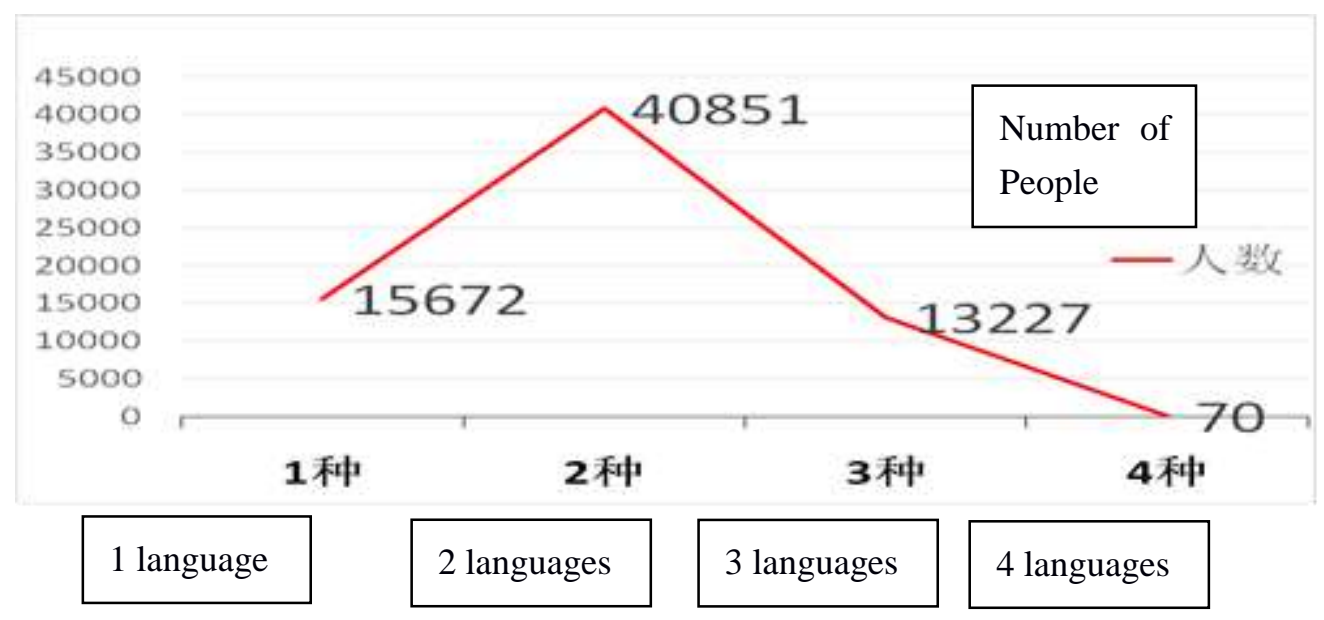


Figure 1 The Condition of Multilingualism of Border Residents in Dongxing, Guangxi

On bilingual occasion, the main patterns are the combination of local mother tongue and Putonghua, such as Gin language and Putonghua, Vernacular and Putonghua, Hakka and Putonghua. People who master ${ }^{9}$ the local mother tongue and Putonghua are the majority, accounting for $99.19 \%$ of the total number of bilingual users, among which Vernacular and Putonghua users are the main part, accounting for $94.98 \%$. However, the number of residents who master the local mother tongue and the languages of neighboring communities, villages and other frequently contacted areas is not large, taking up only $0.79 \%$, such as Vernacular and Gin language, Gin language and Hakka, Vernacular and Hakka, Vernacular and Vietnamese. Only 7 people who were originally outsiders and have settled down by marriage, master Vernacular and Zhuang. Among the residents who use three or more languages, $88.23 \%$ of them has mastered Putonghua. The use of two or more languages in this area is shown in Table 1.

Table 1 Multilingualism of Border Residents in Dongxing, Guangxi

\begin{tabular}{|c|c|c|c|c|c|}
\hline \multicolumn{2}{|l|}{ Bilingualism } & \multicolumn{2}{|c|}{ Trilingualism } & \multicolumn{2}{|c|}{ Quadrilingualism } \\
\hline Languages & $\begin{array}{l}\text { Number } \\
\text { (person) }\end{array}$ & Languages & $\begin{array}{l}\text { Number } \\
\text { (people) }\end{array}$ & Languages & $\begin{array}{l}\text { Number } \\
\text { (people) }\end{array}$ \\
\hline $\begin{array}{l}\text { Gin language, } \\
\text { Vernacular }\end{array}$ & 81 & $\begin{array}{l}\text { Gin } \\
\text { language, } \\
\text { Vernacular, } \\
\text { Putonghua }\end{array}$ & 4,988 & $\begin{array}{l}\text { Gin } \\
\text { language, } \\
\text { Vernacular, } \\
\text { Putonghua, } \\
\text { Hakka }\end{array}$ & 37 \\
\hline $\begin{array}{l}\text { Gin language, } \\
\text { Putonghua }\end{array}$ & 452 & $\begin{array}{l}\text { Gin } \\
\text { language, } \\
\text { Vernacular, } \\
\text { Hakka }\end{array}$ & 1,565 & $\begin{array}{l}\text { Vernacular, } \\
\text { Putonghua, } \\
\text { Zhuang, } \\
\text { Hakka }\end{array}$ & 1 \\
\hline $\begin{array}{l}\text { Gin language, } \\
\text { Hakka }\end{array}$ & 8 & $\begin{array}{l}\text { Gin } \\
\text { language, } \\
\text { Putonghua, } \\
\text { Hakka }\end{array}$ & 1,675 & $\begin{array}{l}\text { Vernacular, } \\
\text { Putonghua, } \\
\text { Hakka, } \\
\text { Vietnamese }\end{array}$ & 30 \\
\hline $\begin{array}{l}\text { Vernacular, } \\
\text { Putonghua }\end{array}$ & 38,799 & $\begin{array}{l}\text { Vernacular, } \\
\text { Putonghua, } \\
\text { Hakka }\end{array}$ & 4,932 & $\begin{array}{l}\text { Putonghua, } \\
\text { Zhuang, } \\
\text { Hakka, } \\
\text { Vietnamese }\end{array}$ & 2 \\
\hline
\end{tabular}

\footnotetext{
9 From the perspective of linguistic proficiency, "master" refers to the attainment of three levels: proficient, competent and barely competent.
} 


\begin{tabular}{|l|l|l|l|l|l|}
\hline $\begin{array}{l}\text { Vernacular, } \\
\text { Zhuang }\end{array}$ & 7 & $\begin{array}{l}\text { Vernacular, } \\
\text { Putonghua, } \\
\text { Vietnamese }\end{array}$ & 60 & & \\
\hline $\begin{array}{l}\text { Vernacular, } \\
\text { Hakka }\end{array}$ & 101 & $\begin{array}{l}\text { Putonghua, } \\
\text { Hakka, } \\
\text { Vietnamese }\end{array}$ & 2 & & \\
\hline $\begin{array}{l}\text { Vernacular, } \\
\text { Vietnamese }\end{array}$ & 132 & & & & \\
\hline Putonghua, Hakka & 1,271 & & & & \\
\hline Total & 40,851 & & 13,227 & & 70 \\
\hline
\end{tabular}

The research group divides the respondent's occupations into seven categories, namely, migrant workers, farmers, businessmen, civil servants, students, other occupations and unemployment. From the match between multilingualism and occupations, nearly $35 \%$ of residents from all occupations (including unemployment) use two or more languages. Among them, civil servants hold the highest proportion, with $70.04 \%$ bilingual speakers; students take second place, accounting for $65.90 \%$. These two groups are comprised of mostly highly educated personnel or students at school, who are all proficient Putonghua users. The proportion of businessmen, migrant workers and peasant workers are also high, accounting for nearly $60 \%$. Because of the need for doing business or going out to work and doing odd jobs, these three types of personnel often speak other languages except their mother tongue. Similarly, due to work needs, civil servants are bilingual or three language users, and the percentage of 4 languages users among business people is the highest, reaching $0.29 \%$. (see Table 2 for details).

Table 2 Multilingualism and Employment of Border Residents in Dongxing City, Guangxi

\begin{tabular}{|c|c|c|c|c|c|c|c|}
\hline $\begin{array}{l}\text { Occupation } \\
\text { Number of } \\
\text { Languages }\end{array}$ & $\begin{array}{l}\text { Migrant } \\
\text { Workers }\end{array}$ & Famers & $\begin{array}{l}\text { Business- } \\
\text { men }\end{array}$ & $\begin{array}{l}\text { Civil } \\
\text { Servants }\end{array}$ & Students & Others & $\begin{array}{l}\text { Unempl- } \\
\text { oyment }\end{array}$ \\
\hline Monolingual & $\begin{array}{l}5,359 \\
(17.93 \%)\end{array}$ & $\begin{array}{l}1,847 \\
(23.72 \%)\end{array}$ & $\begin{array}{l}699 \\
(25.76 \%)\end{array}$ & $\begin{array}{l}25 \\
(10.55 \%)\end{array}$ & $\begin{array}{l}3,539 \\
(17.78 \%)\end{array}$ & $\begin{array}{l}865 \\
(48.27 \%)\end{array}$ & $\begin{array}{l}3,338 \\
(44.57 \%)\end{array}$ \\
\hline Bilingual & $\begin{array}{l}17,357 \\
(58.06 \%)\end{array}$ & $\begin{array}{l}4,595 \\
(59.02 \%)\end{array}$ & $\begin{array}{l}1,603 \\
(59.06 \%)\end{array}$ & $\begin{array}{l}166 \\
(70.04 \%)\end{array}$ & $\begin{array}{l}13,118 \\
(65.90 \%)\end{array}$ & $\begin{array}{l}622 \\
(34.71 \%)\end{array}$ & $\begin{array}{l}3390 \\
(45.26 \%)\end{array}$ \\
\hline Trilingual & $\begin{array}{l}7,144 \\
(23.90 \%)\end{array}$ & $\begin{array}{l}1,329 \\
(17.07 \%)\end{array}$ & $\begin{array}{l}404 \\
(14.89 \%)\end{array}$ & $\begin{array}{l}66 \\
(19.41 \%)\end{array}$ & $\begin{array}{l}3,239 \\
(16.27 \%)\end{array}$ & $\begin{array}{l}304 \\
(16.96 \%)\end{array}$ & $\begin{array}{l}761 \\
(10.16 \%)\end{array}$ \\
\hline Quadrilingual & $\begin{array}{l}36 \\
(0.12 \%)\end{array}$ & $\begin{array}{l}15 \\
(0.19 \%)\end{array}$ & $\begin{array}{l}8 \\
(0.29 \%)\end{array}$ & $\begin{array}{l}0 \\
(0.00 \%)\end{array}$ & $\begin{array}{l}9 \\
(0.05 \%)\end{array}$ & $\begin{array}{l}1 \\
(0.06 \%)\end{array}$ & $\begin{array}{l}1 \\
(0.01 \%)\end{array}$ \\
\hline
\end{tabular}

Note: The data in the tables and brackets are the number of language users (unit: person) and their ratio to the number of people engaged in the same occupation (unit: \%). 


\subsection{Putonghua Proficiency Analysis}

In terms of Putonghua proficiency, 46,134 residents are at the proficient level, reaching $66.08 \% ; 6,005$ people are at the competent level, accounting for $8.6 \% ; 112$ people are barely competent, taking up $0.16 \% ; 17,569$ people are incompetent, accounting for $25.16 \%$ (see Table 3 for details).

Table 3 Putonghua Proficiency of Border Residents in Dongxing City, Guangxi

\begin{tabular}{l|l|l|l|l|l|l|l|l|}
\hline $\begin{array}{l}\text { Langu } \\
\text { age }\end{array}$ & \multicolumn{2}{|l|}{ Proficient } & \multicolumn{2}{l|}{ Competent } & \multicolumn{2}{l|}{ Barely Competent } & \multicolumn{2}{l|}{ Incompetent } \\
\cline { 2 - 8 } $\begin{array}{l}\text { Profici } \\
\text { ency }\end{array}$ & $\begin{array}{l}\text { Number/ } \\
\text { Rerson }\end{array}$ & $\begin{array}{l}\text { Percenta } \\
\text { ge/\% }\end{array}$ & $\begin{array}{l}\text { Number/ } \\
\text { Person } \\
\text { Langu } \\
\text { ages }\end{array}$ & $\begin{array}{l}\text { Percenta } \\
\text { ge/\% }\end{array}$ & $\begin{array}{l}\text { Number/ } \\
\text { Person }\end{array}$ & $\begin{array}{l}\text { Percenta } \\
\text { ge/\% }\end{array}$ & $\begin{array}{l}\text { Number/ } \\
\text { Person }\end{array}$ & $\begin{array}{l}\text { Percenta } \\
\text { ge/\% }\end{array}$ \\
\hline $\begin{array}{l}\text { Putong } \\
\text { hua }\end{array}$ & 46,134 & 66.08 & 6,005 & 8.60 & 112 & 0.16 & 17,569 & 25.16 \\
\hline
\end{tabular}

In the pairs of Putonghua proficiency and occupations, the vast majority (more than $70 \%$ ) of the residents engaged in migrant working, farming, business, civil service, students and other occupations, have reached the barely competent, competent or proficient level, but among the group of other occupations and unemployed, the one with incompetent level accounts for $49.27 \%$ and $46.32 \%$, respectively, only $53.68 \%$ and $50.73 \%$ of the residents reaching the barely competent level or above. And $62 \%$ and $60 \%$ of the corresponding population are at barely competent level (see Table 4 for details).

Table 4 The Match Between Putonghua Proficiency and Occupation of Border Residents in Dongxing City, Guangxi

\begin{tabular}{|c|c|c|c|c|c|c|c|}
\hline $\begin{array}{l}\text { Occupation } \\
\text { Proficiency }\end{array}$ & $\begin{array}{l}\text { Migrant } \\
\text { Workers }\end{array}$ & Farmers & $\begin{array}{l}\text { Business- } \\
\text { men }\end{array}$ & $\begin{array}{l}\text { Civil } \\
\text { Servants }\end{array}$ & Students & Others & $\begin{array}{l}\text { Unemploy- } \\
\text { ment }\end{array}$ \\
\hline Incompetency & $\begin{array}{l}6,481 \\
(21.68 \%)\end{array}$ & $\begin{array}{l}1,922 \\
(24.69 \%)\end{array}$ & $\begin{array}{l}783 \\
(28.86 \%)\end{array}$ & $\begin{array}{l}26 \\
(10.97 \%)\end{array}$ & $\begin{array}{l}4,005 \\
(20.12 \%)\end{array}$ & $\begin{array}{l}883 \\
(49.27 \%)\end{array}$ & $\begin{array}{l}3,469 \\
(46.32 \%)\end{array}$ \\
\hline Mastery ${ }^{10}$ & $\begin{array}{l}23,415 \\
(78.32 \%)\end{array}$ & $\begin{array}{l}5,864 \\
(75.31 \%)\end{array}$ & $\begin{array}{l}1,931 \\
(71.14 \%)\end{array}$ & $\begin{array}{l}211 \\
(89.03 \%)\end{array}$ & $\begin{array}{l}15,900 \\
(79.88 \%)\end{array}$ & $\begin{array}{l}909 \\
(50.73 \%)\end{array}$ & $\begin{array}{l}4,021 \\
(53.68 \%)\end{array}$ \\
\hline
\end{tabular}

Note: The data in the tables and brackets are the number of language users (unit: person) and their ratio to the number of people engaged in the same occupation (unit: \%).

\footnotetext{
10 The "Mastery" group, here, refers to residents who have reached the proficient, competent and barely competent level of Putonghua.
} 


\subsection{Cross-border Language (Gin language) Proficiency Analysis}

Apart from Putonghua, the Chinese dialects and ethnic languages are spoken by border residents in Dongxing include Vernacular (a branch of Cantonese dialect) ${ }^{11}$, Hakka, Gin language ${ }^{12}$ and Zhuang. Among them, Vernacular (Cantonese) is the mother tongue of the vast majority of the residents in these border areas. Hakka is also known as Hakka Chinese, the mother tongue of the Hakka family the Han, and is the common language of the Hakka people in Dongxing City; Zhuang language, that is, the main language used by Zhuang people in Dongxing City; the Gin language is commonly used by Gin people in Dongxing City. And the Gin is also the main ethnic group in Vietnam, accounting for $90 \%$ of the total population. Therefore, Gin language can be regarded as the cross-border language of Dongxing border residents. According to the survey results, 8,806 residents, accounting for $12.56 \%$ of the total respondents, are Gin language users and they are all residents of Wutou, Wanwei and Shanxin islands in Jiangping Town, Dongxing City, commonly known as "Three Islands of Gin People". Among all respondents, 8,766 people reach proficient level, 39 competent, 1 barely competent, and 61,014 incompetent, accounting for $12.56 \%, 0.06 \%, 0.01 \%$ and $87.39 \%$ respectively (see Table 5 for details). The match between the cross-border language (Gin language) proficiency and occupations of Dongxing border residents are shown in Table 6.

Table 5 Dialect Proficiency of Border Residents in Dongxing City, Guangxi

\begin{tabular}{l|l|l|l|l|l|l|l|l|}
\hline $\begin{array}{l}\text { Langu } \\
\text { age } \\
\text { Profici } \\
\text { ency }\end{array}$ & \multicolumn{2}{|l|}{ Proficient } & \multicolumn{2}{l|l}{ Competent } & \multicolumn{2}{l|}{ Barely Competent } & \multicolumn{2}{l|}{ Incompetent } \\
\cline { 2 - 8 } & $\begin{array}{l}\text { Number/ } \\
\text { Lerson } \\
\text { ages }\end{array}$ & $\begin{array}{l}\text { Percenta } \\
\text { pe/\% }\end{array}$ & $\begin{array}{l}\text { Percenta } \\
\text { ge/\% }\end{array}$ & $\begin{array}{l}\text { Number/ } \\
\text { person }\end{array}$ & $\begin{array}{l}\text { Percenta } \\
\text { ge/\% }\end{array}$ & $\begin{array}{l}\text { Number/ } \\
\text { person }\end{array}$ & $\begin{array}{l}\text { Percenta } \\
\text { ge/\% }\end{array}$ \\
\hline $\begin{array}{l}\text { Gin } \\
\text { langua } \\
\text { ge }\end{array}$ & 8,766 & 12.56 & 39 & 0.06 & 1 & 0.01 & 61,014 & 87.39 \\
\hline
\end{tabular}

Table 6 The Match Between Dialect Proficiency and Occupations of Border Residents in Dongxing City, Guangxi

\begin{tabular}{l|l|l|l|l|l|l|l|}
\hline $\begin{array}{l}\text { Occupations } \\
\text { Languages }\end{array}$ & $\begin{array}{l}\text { Migrant } \\
\text { Workers }\end{array}$ & Farmers & Businessmen & $\begin{array}{l}\text { Civil } \\
\text { Servants }\end{array}$ & Students & Others & Unemployment \\
\hline Gin Language & $\begin{array}{l}5,228 \\
(59.37 \%)\end{array}$ & 236 & 361 & 33 & 2,258 & 281 & 409 \\
$(2.68 \%)$ & $(4.10 \%)$ & $(0.37 \%)$ & $(25.64)$ & $(3.19 \%)$ & $(4.65 \%)$ \\
\hline
\end{tabular}

Note: Data in tables and brackets are the number of language users (unit: person) and their proportion in the total number (unit: \%).

\footnotetext{
11 The reason why Dongxing Vernacular in Guangxi is called a branch of Cantonese dialect is that there are differences in accent between Dongxing Vernacular (Cantonese) in Guangxi and Vernacular (Cantonese) in Guangdong due to the influence from other local ethnic languages.
}

\footnotetext{
12 Gin language is the main language used by Gin people. Gin people in mainland China mainly distribute in Wutou, Wanwe and Shanxin islands in Jiangping Town, Dongxing City, Guangxi Province, commonly known as the "Three Islands of Gin People". Although Gin language and Vietnamese are cognate, there are some differences in pronunciation between the two, because of the former's contact and integration with other ethnic languages in Dongxing, China.
} 


\subsection{Foreign Language (Vietnamese) Proficiency Analysis}

Vietnamese is the official language of Vietnam. Mastering Vietnamese on part of border residents of Dongxing is conducive to strengthening exchanges and contact between the residents of the two countries. Thus, the research group mainly investigates the Vietnamese ability of the residents. The survey shows that the respondent's Vietnamese is relatively not good enough, with only 227 people $(0.33 \%)$ having the barely competent proficiency. Among them, 86 are migrant workers, 23 farmers, 70 businessmen, 1 civil servant, 22 students, 22 other professionals and 3 unemployed persons ${ }^{13}$ accounting for $37.89 \%, 10.13 \%, 30.84 \%, 0.44 \%$, $9.69 \%$ and $1.32 \%$ respectively (see Table 7 for details).

Table 7 The Cross-border Language Proficiency of Border Residents in Dongxing City, Guangxi

\begin{tabular}{|c|c|c|c|c|c|c|c|c|}
\hline $\begin{array}{l}\text { Langu } \\
\text { age } \\
\text { Profici } \\
\text { ency }\end{array}$ & \multicolumn{2}{|l|}{ Proficient } & \multicolumn{2}{|c|}{ Competent } & \multicolumn{2}{|c|}{ Barely Competent } & \multicolumn{2}{|c|}{ Incompetent } \\
\hline $\begin{array}{l}\text { ency } \\
\text { Langu } \\
\text { ages }\end{array}$ & $\begin{array}{l}\text { Number/ } \\
\text { pexson }\end{array}$ & $\begin{array}{l}\text { Percenta } \\
\text { ge/\% }\end{array}$ & $\begin{array}{l}\text { Number/ } \\
\text { person }\end{array}$ & $\begin{array}{l}\text { Percenta } \\
\text { ge/\% }\end{array}$ & $\begin{array}{l}\text { Number/ } \\
\text { person }\end{array}$ & $\begin{array}{l}\text { Percenta } \\
\text { ge/\% }\end{array}$ & $\begin{array}{l}\text { Number/ } \\
\text { person }\end{array}$ & $\begin{array}{l}\text { Percenta } \\
\text { ge/\% }\end{array}$ \\
\hline $\begin{array}{l}\text { Vietna } \\
\text { mese }\end{array}$ & 67 & 0.10 & 132 & 0.19 & 28 & 0.04 & 69,593 & 99.67 \\
\hline
\end{tabular}

\section{An Analysis of Border Resident's Income in Dongxing City}

\subsection{Income Hierarchy Analysis}

According to the income level of border residents, the research group divides the average annual income into four groups, namely, 0-20,000 yuan, 20,001-36,000 yuan, 36,001-72,000 yuan and 72,001 yuan or more. Among the residents surveyed, 45,933 (65.79\%) people belong to $0-20,000$ yuan group, 22,606 (32.38\%) people to 20,001-36,000 yuan group, 997 (1.43\%) people to 36,001-72,000 yuan group, and 284 (0.40\%) people to 72,001 yuan or more group. The lower the income level is, the higher the proportion is; and the higher the income level is, the lower the proportion is (see Table 8 for details).

Table 8 Border Resident's Income in Dongxing City

\begin{tabular}{|c|c|c|c|c|c|c|c|}
\hline \multicolumn{2}{|c|}{ 0-20,000 Yuan } & \multicolumn{2}{|c|}{ 20,001-36,000 Yuan } & \multicolumn{2}{|c|}{$36,001-72,000$ Yuan } & \multicolumn{2}{|c|}{72,001 Yuan or more } \\
\hline $\begin{array}{c}\text { Number/ } \\
\text { person }\end{array}$ & Percentage/\% & Number/person & Percentage/\% & Number/person & Percentage/\% & Number/person & Percentage/\% \\
\hline 45,933 & 65.79 & 22,606 & 32.38 & 997 & 1.43 & 284 & 0.40 \\
\hline
\end{tabular}

\subsection{The Income of Residents with Different Occupations}

13 The Vietnamese-speaking residents of other occupations and unemployment groups are all Vietnamese who have been married to Dongxing local residents. 
The survey results show that there is a large income gap among residents engaged in different occupations. Among them, the average annual income of migrant workers, farmers, businessmen, civil servants, students, other professionals and unemployed persons is 29,093 yuan, 20,792 yuan, 77,844 yuan, 32,510 yuan, 5,000 yuan ${ }^{14}, 16,613$ yuan and 10,184 yuan $^{15}$, respectively. The income of Business residents is the highest, and that of students is the lowest (see Table 9 for details).

Table 9 Occupations and Annual Income Distribution of Border Residents in Dongxing City

\begin{tabular}{|c|c|c|c|c|c|c|c|c|}
\hline \multirow{2}{*}{$\begin{array}{l}\text { Income } \\
\text { Interval }\end{array}$} & \multicolumn{7}{|c|}{ The Number of People (person) } & \multirow{2}{*}{ Total } \\
\hline & \begin{tabular}{|l|} 
Migrant \\
Workers
\end{tabular} & Farmers & $\begin{array}{l}\text { Business- } \\
\text { men }\end{array}$ & $\begin{array}{l}\text { Civil } \\
\text { Servants }\end{array}$ & Students & Others & Unemployment & \\
\hline $0-20,000$ & 9,166 & 7,649 & 153 & 35 & 19,904 & 1,612 & 7,413 & 45,933 \\
\hline $\begin{array}{l}20,001- \\
36,000\end{array}$ & 20,256 & 85 & 1,870 & 190 & 1 & 147 & 57 & 22,606 \\
\hline $\begin{array}{l}36,001- \\
72,000\end{array}$ & 433 & 42 & 465 & 11 & 0 & 29 & 18 & 997 \\
\hline $\begin{array}{l}72,000 \text { or } \\
\text { more }\end{array}$ & 41 & 10 & 226 & 1 & 0 & 4 & 2 & 284 \\
\hline Total & 29,896 & 7,786 & 2,714 & 237 & 19,905 & 1,792 & 7,490 & 69,820 \\
\hline $\begin{array}{l}\text { Annual } \\
\text { Average } \\
\text { Income } \\
\text { (Yuan) }\end{array}$ & 29,093 & 20,792 & 77,844 & 32,510 & 5,000 & 16,613 & 10,184 & \\
\hline
\end{tabular}

\section{An Analysis of the Correlation Between Language Proficiency and Income of Border Residents in Dongxing City}

\subsection{An Analysis of the Correlation Between Multilingual Proficiency and Income}

The survey found that among the 15,672 monolingual users, $63.93 \%$ of them falls in the $0-20,000$ yuan group, $34.91 \%$ in $20,001-36,000$ yuan group, $0.96 \%$ in $36,001-72,000$ yuan group, and $0.20 \%$ in the group of 72,001 yuan or more. Within the 40,851 bilingual speakers, $70.38 \%$ of them belongs to the group of $0-20,000$ Yuan, $27.83 \%$ to $20,001-36,000$ Yuan group, $1.32 \%$ to $36,001-72,000$ yuan group, and $0.47 \%$ to 72,001 yuan or more group. Among the 13,227 trilingual speakers, $0-20,000$ yuan group accounts for 53.87\%, 20,001-36,000 yuan group for $43.42 \%, 36,001-72,000$ yuan group for $2.27 \%$, and 72,000 yuan or more group for $0.44 \%$. Within the 70 quadrilingual users, the percentage of the average annual income of each income group is $51.43 \%, 41.43 \%$, $5.71 \%$, and $1.43 \%$ respectively. Among those groups, a higher proportion of high-income goes to the group of trilingual and four or more languages users, and their proportion in the last two income groups is $4.75 \%$ and

14 The income of the student group mainly comes from part-time jobs done by College students, undergraduates and postgraduates over the age of 18 .

15 Since more than $90 \%$ of the unemployed residents are elderly people over 60 years old, their income mainly comes from the border people's allowance, pension and old age allowance. 
$1.23 \%$ higher than that of monolingual users, respectively. By calculation, the average annual income of monolingual, bilingual, trilingual, quadrilingual users is 23,435 yuan, 34,154 yuan, 36,042 yuan, and 49,001 yuan respectively. The average annual income of people who can speak two or more languages is 10,719 yuan, 12,607 yuan and 25,566 yuan higher than that of monolingual speakers accordingly (see Table 10 for details).

Table 10 Multilingual Proficiency and Average Annual Income of Border Residents in Dongxing City

\begin{tabular}{|c|c|c|c|c|c|}
\hline \multirow{2}{*}{$\begin{array}{l}\text { Multilingual } \\
\text { Proficiency }\end{array}$} & \multicolumn{4}{|c|}{ The Proportion of each Income Interval } & \multirow{2}{*}{$\begin{array}{l}\text { Annual Average } \\
\text { Income } \\
\text { (Yuan) }\end{array}$} \\
\hline & $\begin{array}{l}\text { 0-20,000 } \\
\text { Yuan }\end{array}$ & $\begin{array}{l}20,001-36,000 \\
\text { Yuan }\end{array}$ & $\begin{array}{l}36,001-72,000 \\
\text { Yuan }\end{array}$ & $\begin{array}{l}72,001 \text { Yuan } \\
\text { or more }\end{array}$ & \\
\hline Monolingual & $71.93 \%$ & $26.91 \%$ & $0.96 \%$ & $0.20 \%$ & 23,435 \\
\hline Bilingual & $70.38 \%$ & $27.83 \%$ & $1.32 \%$ & $0.47 \%$ & 34,154 \\
\hline Trilingual & $53.87 \%$ & $43.42 \%$ & $2.27 \%$ & $0.44 \%$ & 36,042 \\
\hline Quadrilingual & $51.43 \%$ & $41.43 \%$ & $5.71 \%$ & $1.43 \%$ & 49,001 \\
\hline
\end{tabular}

A preliminary ${ }^{16}$ conclusion can be drawn from the above analysis that there is a positive correlation between the multilingual proficiency and the average income of the border residents in Dongxing City, that is, the stronger the multilingual ability is, the greater the possibility of high income can be.

\subsection{An Analysis of the Correlation Between Putonghua Proficiency and Income}

According to the survey, Putonghua is a common language for many people in multilingualism. Especially in foreign exchanges, Putonghua has become the language spoken by most people. Table 11 shows that people who master Putonghua are more likely to earn a higher income. Among the incompetent language users, $38.49 \%$ of them earn more than 20,001 yuan, while within the residents whose language grades are at and above barely competent level, the proportion reaches $42.34 \%$, which is $3.58 \%$ higher than the former. As for the average annual income, the former group earns 17,304 yuan lower than the latter, and the monthly average income is lowered nearly by 1,500 yuan. Further research shows that the promotion of Putonghua is conducive to border residents to do migrant work or do business in Dongxing City, and it has a positive effect on promoting the transfer and employment of rural surplus labor force in the border areas between China and Vietnam. Among the migrant workers and businessmen in this area, $96.47 \%$ and $95.73 \%$ of them have mastered Putonghua, respectively. This is also consistent with the conclusions of theoretical and empirical studies of linguistic economics at home and abroad ${ }^{17}$.

Table 11 Putonghua Proficiency and the Average Annual Income of Border Residents in Dongxing City, Guangxi

16 The reason for arriving at a "preliminary" conclusion is that according to Wang Chunhui (2019), language competence is a probability rather than a sufficient and necessary condition for the improvement of economic income. And the analysis here is a bilateral variable regression based on questionnaire data, or through simple graphic analysis such as pie charts and bar charts, whose results have not been discussed in depth through constructing multiple regression model, Likert-scale and the like.

17 The theoretical and empirical studies of linguistic economics at home and abroad show that barriers to language communication are important constraints to the leapfrogging flow of labor force and migrant workers in the market. Lack of linguistic skills will lead to "linguistic discrimination" of minority labor force in the market (Chiswick, 1991; Carnevale, et al., 2001; Xu Xianxiang, Liu Yuyun, 2015; Liu Guohui and Zhang Weiguo, 2016). 


\begin{tabular}{|c|c|c|c|c|c|}
\hline \multirow{2}{*}{$\begin{array}{l}\text { Putonghua } \\
\text { Proficiency }\end{array}$} & \multicolumn{4}{|c|}{$\begin{array}{l}\text { The Number of People (person) and the Proportion (\%) in } \\
\text { each Income Interval }\end{array}$} & \multirow{2}{*}{$\begin{array}{l}\text { Annual } \\
\text { Average } \\
\text { Income } \\
\text { (Yuan) }\end{array}$} \\
\hline & $0-20,000$ Yuan & $\begin{array}{l}20,001- \\
36,000 \text { Yuan }\end{array}$ & $\begin{array}{l}36,001- \\
72,000 \text { Yuan }\end{array}$ & $\begin{array}{l}72,001 \text { Yuan } \\
\text { or more }\end{array}$ & \\
\hline Incompetent & $\begin{array}{l}10,806 \\
(61.51 \%)\end{array}$ & $\begin{array}{l}6,496 \\
(36.97 \%)\end{array}$ & $\begin{array}{l}214 \\
(1.22 \%)\end{array}$ & $\begin{array}{l}53 \\
(0.3 \%)\end{array}$ & 23,728 \\
\hline $\begin{array}{l}\text { Mastery (at } \\
\text { and above the } \\
\text { barely } \\
\text { competent } \\
\text { level) }\end{array}$ & $\begin{array}{l}30,127 \\
(57.66 \%)\end{array}$ & $\begin{array}{l}21,110 \\
(40.4 \%)\end{array}$ & $\begin{array}{l}783 \\
(1.5 \%)\end{array}$ & $\begin{array}{l}231 \\
(0.44 \%)\end{array}$ & 40,762 \\
\hline
\end{tabular}

\section{Note: The data in brackets are the proportion of residents in each income interval, unit: \%.}

This research shows that the impact of Putonghua popularization rate on economic growth is of minimal scale. At a certain stage of Putonghua popularization, the cost is greater than the economic benefits, which results in a negative effect on economic growth. However, when the rate exceeds a certain scale, its impact on economic growth turns to be positive. Meanwhile, our quantitative research results indicate that the minimum rate of Putonghua popularization is $60 \%-63.8 \%$, that is to say, in order to produce a positive effect on economic development, we must ensure that the popularization rate is higher than $60 \%{ }^{18}$. The survey of language living conditions of border residents in Dongxing City shows that the total number of border residents is 69,820 , and 52,251 people master Putonghua, accounting for $74.84 \%$. Thus, the popularization rate has exceeded the minimum scale of $60 \%-63.8 \%$. Therefore, this language element will produce a continuous and positive effect on the implementation of the economic development strategy and poverty alleviation in this city.

At the same time, in the process of our investigation and interview, most residents believe that it is necessary to protect and inherit the local language and culture. For example, in the Gin minority area, traditional festivals have been always maintained, and the language has been well preserved, with the intra-ethnic communication almost all in Gin language. The local children learn Gin language as the first language, Vernacular as the second language, and they begin to communicate in Putonghua after they go to school. While they hope to maintain their mother tongue and traditional culture for a long time, they also wish that future generations will learn Putonghua well, have better communication with the outside world and get more job opportunities. In Shengou community, children learn Putonghua first, and the phenomenon of speaking Putonghua among children and adolescents is increasing year by year. However, the communication within families and communities is in Vernacular. They believe that learning Putonghua is very important, which will not affect the use of local languages, but will help them a lot go out to work, study and do business. The promotion of Putonghua has no obvious influence on the use of minority languages. There is no evidence showing that the promotion of Putonghua will lead to the decline of minority languages in this area. However, according to the on-the-spot investigation of the research group, the traditional culture of ethnic minorities (except the Gin culture) in the border areas of Dongxing City has been gradually weakened or even disappeared. Therefore, given the conflict between the high popularization rate of Putonghua among the residents and the decline of the local minority culture, the government of Dongxing City should optimize and improve the local industrial policy, strive to tap

18 See details in Bian Chenglin, Liu Jinlin, Yang Liuyan and Sudan: Economic Development Effect Analysis of Putonghua Promotion in Ethnic Minority Areas: Evidence from Intercity Panel Data in Guangxi [J], Institutional Economics Research, No. 3, 2017. 
the local minority cultural specialities, and develop minority cultural industries, while emphasizing the promotion of Putonghua and giving full play to its economic and social benefits. Meanwhile, in the process of cultivating new economic impetus, the government should promote and protect the traditional culture of ethnic minorities.

\subsection{An Analysis of the Correlation Between Cross-border Languages (Gin Language) Proficiency and Income}

The users of Gin language are all from Wutou, Wanwei and Shanxin islands in Jiangping Town of Dongxing City, commonly known as the residents of "Three Islands of Gin People". In the field investigations, the research team found that Gin people have 13 items at all levels listed in the intangible cultural heritage protection projects, including 2 national items-Hajie Festival ${ }^{19}$ and the Solo Stringed Instrument, 3 provincial items-the fish sauce, the costume and the folk songs, 1 municipal item - the Nan character of the Gin which has been listed in Fangchenggang city-level intangible cultural heritage list, 8 items at county level, such as the traditional narrative songs and Hage songs which have been listed in Dongxing protection projects. In this sense, the traditional Gin culture has been well inherited and protected. The Gin residents make full use of the geographical advantages of this coast and border area to develop vigorously such industries as marine fishing, mariculture, seafood processing, tourism and frontier trade, especially the three major industries of marine tourism, catering services and seafood processing and marketing. They have paved an economic development path characterized by "raising while catching, combining agriculture and commerce, and integrating three industries". In the 1980s, many Gin people lived a precarious and insufficient life. They only depended on seafood to make an exchange for rice, oil and salt. After the reform and opening up, they have enjoyed the "meal of opening up", and every household has engaged in frontier trade, which has brought about great changes in their lives. Nowadays, their net per capita income is over 20,000 yuan, and "every family having a house and a car" is a true portrayal of the life of "Three Islands of Gin People". The Gin has become one of the ethnic minorities with the fastest economic and social development in China and one of the richest ethnic groups in China. The results of the survey reveal that the average annual income of the residents who master Gin language is 90,586 yuan, which is much higher than that of those who master Putonghua and other languages (except Vietnamese). In terms of occupation types, given the geographical advantages and the similar customs and languages with Vietnamese residents, local odd jobs, farming and business are the main kinds of jobs in this area with workers reaching $88.96 \%$ of Gin language users (except students). Border trade, marine fishing, aquaculture, tourism and catering services are the main source of income for local residents. Odd jobs refer to mainly the work in local tourism, seafood processing and marketing enterprises, tourism catering industry and aquaculture industry, with an average annual income of 87,425 yuan per capita; farming mainly focuses on marine fishing, with an average annual income of 63,520 yuan per capita; border trade is the main mode of business, with an average annual income of 247,820 yuan per capita, much higher than that of odd job workers and farmers, which is consistent with the survey results of Wang Zhongli (2012) ${ }^{20}$ on "Yunnan people" in Laos.

\subsection{An Analysis of the Correlation Between Foreign Languages (Vietnamese) Proficiency and Income}

The fieldwork findings indicate that although there are fewer Vietnamese speakers, only 227 people, most of them are engaged in Sino-Vietnamese trade and business. And even some of them are the chairmen and general managers of Sino-Vietnamese trading companies, so their income is much higher than that of other residents in the border area. In Vietnamese language proficiency, 227 people have reached above the barely competent level, of which 128 residents are at the proficient and competent level, including 5 migrant workers, 5 peasant workers, 70 businessmen, 1 civil servant, 22 students, 22 other professionals and 3 unemployed persons.

19 "Hajie Festival" is a traditional festival of Gin people. "Ha" means "singing" in Gin language. Hajie Festival is celebrated to commemorate the birth of the God of the sea.

20 Wang Zhongli, a Chinese scholar, has investigated the "Yunnan people" (referring to the overseas Chinese who speak Yunnan Chinese dialect) in Laos, and found that their complex and diverse language life has enabled them to acquire rich language resources and strong multilingual communicative competence. Therefore, many people have succeeded in border trade by virtue of this advantage. 
Through comparison, it is found that 16 out of these 128 people earn more than 70,000 yuan, and 65 people out of them who are proficient speakers make 380,500 yuan per year on average, which is much higher than that of other residents in Dongxing City. As shown in Table 12, the average annual income of Vietnamesespeaking residents with a proficiency level of above barely competent is 94,500 yuan higher than that of incompetent ones, and their average monthly income is nearly 8,000 yuan higher than that of the latter. In this way, while giving full play to Dongxing's geographical advantages, improving Vietnamese proficiency as a foreign language is beneficial to the communication between Dongxing border people and Vietnamese businessmen and to the reduction of communication cost in Sino-Vietnamese trade. And in turn, it can promote the prosperity of Sino-Vietnamese border trade and increase the income of Sino-Vietnamese border residents. This conclusion agrees with the research results on "language distance and international trade relations" at home and abroad ${ }^{21}$. It also gives a reasonable explanation to the "Vietnamese fever" in Dongxing City in recent years.

Table 12 Vietnamese Proficiency and the Average Annual Income of Border Residents in Dongxing City, Guangxi

\begin{tabular}{|c|c|c|c|c|c|}
\hline \multirow{2}{*}{ Vietnamese Proficiency } & \multicolumn{4}{|c|}{$\begin{array}{l}\text { The Number of People in each Income Interval } \\
\text { (person) }\end{array}$} & \multirow{2}{*}{$\begin{array}{l}\text { Annual } \\
\text { Average } \\
\text { Income } \\
\text { (Yuan) }\end{array}$} \\
\hline & $\begin{array}{l}0-20,000 \\
\text { Yuan }\end{array}$ & $\begin{array}{l}20,001- \\
36,000 \\
\text { Yuan }\end{array}$ & $\begin{array}{l}36,001- \\
72,000 \text { Yuan }\end{array}$ & $\begin{array}{l}72,001 \\
\text { Yuan or } \\
\text { more }\end{array}$ & \\
\hline Incompetent & 45,828 & 22,511 & 977 & 277 & 35,940 \\
\hline $\begin{array}{l}\text { Mastery (at and above } \\
\text { the barely competent } \\
\text { level) }\end{array}$ & 124 & 22 & 16 & 65 & 130,440 \\
\hline
\end{tabular}

\section{Conclusions}

Based on the results of a full-sample survey of border residents in Dongxing City, Guangxi and the theory of linguistic economics, this paper makes a preliminary analysis of the relationship between language proficiency and income of border residents in this area. The conclusions are as follows:

First, there is a positive correlation between the multilingual ability and the average annual income of residents. That is, the stronger the multilingual ability is, the greater the possibility of obtaining high income can be. This is consistent with the conclusions of Wang Chunhui (2018c) and Wang Haoyu (2019). They believe that monolingualism (especially minority language users who only know their local dialects) has a negative impact on economic income, and learning a common language and then becoming bilingual users can produce a positive impact on economic income. However, although the multilingualism in Dongxing City is relatively common, with $77.55 \%$ of users speaking more than two languages, there are still 15,672 residents who can only use local dialects or ethnic languages, which greatly limits their employment territory and professional scope. Therefore, in addition to mastering local dialects, this part of the border residents should also strengthen their

$21 \quad$ Since Tinbergen (1962), Linnemann (1966) and other scholars applied gravity model to the measurement of inter-country trade flows, as an important form of the cost of foreign trade transactions, the impact of language on international trade flows has attracted more and more attention from scholars, and a number of empirical studies on language and trade flows have emerged (Hutchinson, 2002, 2005; Melitz, 2008; Ku and Zussman, 2010; Su Jian, Ge Jiaguo, 2013). The conclusion of the above research shows that language distance is inversely proportional to international trade flow, reducing the linguistic and cultural differences between countries is conducive to promoting trade exchanges. 
learning of Putonghua, Vietnamese, Gin and other languages in order to enhance their employability and obtain more employment opportunities and stable sources of income.

Second, Putonghua promotion is an effective measure to push forward the poverty alleviation process of border residents between China and Vietnam. Domestic scholars such as Li Yuming (2019), believe that a country's dominant language (often the national language or the official language) has functional advantages. By enhancing the dominant language proficiency and building the bilingual ability, people in poverty areas can have better opportunities to enjoy more public resources and various advantages in language function. Putonghua promotion is beneficial for border residents to work or do business outside their communities, and thus it has a positive role in promoting the transfer of rural surplus labor force in the border areas between China and Vietnam, and in elevating their income. At present, $74.84 \%$ of the residents in Dongxing border area have reached above the barely competent level in Putonghua proficiency, which has met the minimum scale of $60 \%-63.8 \%$. This language element will provide basic and key guarantee for the sustainable, stable development of Dongxing regional economy, and for the realization of the goal of building a well-off society in an all-round way. However, due to the conflict between the high popularity of Putonghua and the decline of the local minority culture, the government should tap and integrate the local characteristic and superior ethnic cultural resources in-depth, while actively promoting Putonghua and building a strong language foundation for poverty alleviation. Through perfecting the characteristic cultural industry chains and building distinctive cultural industry clusters which are taken as important strategies of rural revitalization, the government can deepen "the infusion of minority culture into industry", realize the high integration of minority culture and industrial development, and achieve a win-win situation combining the inheritance and protection of minority culture with the cultivation of new economic impetus.

Third, the cross-border language (Gin language) is not only an important tool of regional international communication and cultural carrier but also a crucial economic resource. The inhabitants of the "Three Islands of Gin People" give full play to the advantages of this language which is similar to Vietnamese, the close customs and habits, and the adjacent geographical location with Vietnam, in their efforts of creating an economic development model which features in the "combination of agriculture and commerce" and "integration of three industries". The former brings the "marine fishing, aquaculture, seafood processing and marketing, and seafood frontier trade" together, whereas the latter links "seafood fishing and breeding, seafood production and marketing" with "marine tourism". This economic model has realized the full employment of the residents, greatly broadened their income channels, and increased their income. Thus, Dongxing Municipal Government should formulate policies for the language industry, develop vigorously the cross-border language products and promote the cross-border language industry, in order to further strengthen the development of crossborder business and trade, and tap fully the economic resource value of Gin language, as a cross-border language.

Fourth, mastering Vietnamese is beneficial for border people to participate in and operate border trade, and to obtain a higher level of wages and operating income. Improving Vietnamese proficiency has a favorable effect on the communication between the border people of Dongxing City and Vietnamese businessmen, and on the reduction of the communication cost of Sino-Vietnamese trade. Therefore, it is of great significance not only to promote the prosperity of such trade but also to increase the income of the residents in related areas. The analysis shows that the average annual income of Vietnamese-speaking residents who have attained above the barely competent level is 94,500 yuan higher than that of those who cannot speak the language, and the former's monthly income is nearly 8,000 yuan higher than that of the latter. Therefore, as this kind of trade progress, Dongxing border residents should focus on strengthening their study of Vietnamese in building their multilingual ability so as to give full play to Dongxing's geographical advantages and elevate their skills in communicating with Vietnamese businessmen, and to guarantee their success in the engagement, participation and operation in Sino-Vietnamese border trade. 


\section{Reference}

1. 张卫国 2016 语言的经济学分析：一个基本框架[M]，北京：中国社会科学出版社。

2. 张卫国 2008 作为人力资本、公共产品和制度的语言:语言经济学的一个基本分析框架[J].经济研究,第2 期。

3. 卡成林 2018 深度贫困地区脱贫的语言要素[N].光明日报（理论版），9月25日。

4. 卡成林、刘金林、阳柳艳、苏丹 2017少数民族地区普通话推广的经济发展效应分析：来自广西市际面 板数据的证据[J].制度经济学研究，第3期。

5. 徐现祥、刘毓芸、肖泽凯 2015 劳动力跨方言流动的倒U型模式[J].经济研究，第10期。

6. 林建浩、赵子乐 2017 均衡发展的隐性壁垒：方言、制度与技术扩散[J].经济研究，第 9 期。

7. 赵子乐、林建浩 2017 经济发展差距的文化假说：从基因到语言[J].管理世界，第1期。

8. 苏剑、黄少安 2015 语言距离的测度及其在经济学中的应用[J].江汉论坛，第3期。

9. 刘玉屏 2010 农民工语言再社会化实证研究一一以浙江省义乌市为个案[J].语言文字应用, 第2期。

10. 戴曼纯、潘巍巍 2018 国家语言能力建设视角下的个人多语能力[J]. 语言文字应用, 第1期。

11. 王连清 1984 三岛京语和河内京语语音初步比较[J].语言研究, 第2期。

12. 李宇明 2015“一带一路”需要语言铺路[N],人民日报，9月22日第7版。

13. 王春辉 2018 论语言因素在脱贫攻坚中的作用[J], 江汉学术, 第5期。

14. 王浩宇 2019 藏区青年一代语言能力与社会经济地位的关系[J].语言战略研究，第1期。

15. 王海兰 2018 深化语言扶贫, 助力脱贫攻坚[N], 中国社会科学报, 9月11日第3版。

16. 李宇明、王春辉 2019 论语言的功能分类[J], 当代语言学, 第1期。

17. 苏剑、葛加国 2013 基于引力模型的语言距离对贸易流量的实证研究: 来自中美两国的数据[J], 经济管 理评论，第4期。

18. 刘国辉、张卫国 2016 中国城市劳动力市场中的“语言经济学” : 外语能力的工资效应研究[J], 山东大学 学报 (哲学社会科学版), 第2期。

19. 赵世举 2016 跨境语言的资源价值[J].语言政策与语言规划研究，第2期。

20. 黄行 2013 中国周边语言研究的意义和价值[J].中国语言资源动态，第4期。

21. 李锦芳 2013 ; 论中越跨境语言[J].百色学院学报, 第4期。

22. 王仲黎 2012 老挝跨境“云南人”语言生活调查[J].西南边疆民族研究，第1期。

23. Breton, Albert, (1998) .Ed. Economic Approaches to Language and Bilingualism. New Canadian Perspectives. Department of Economics University of Toronto.

24. Lohmann, Johannes. (2011). Do Language Barriers Affect Trade? Economics Letters110(2): 159-262. 
25. Tinbergen, J. (1962). An Analysis of World Trade Flows Shaping the World Economy, New York: Twentieth Century Fund.

26. Linnemann, H. (1967). An Econometric Study of International Trade Flows. The Canadian Journal of Economics and Political Science 33(4):633-634.

27. Hutchinson, W. K. (2002). Does Ease of Communication Increase Trade? Commonality of Language and Bilateral Trade. Scottish Journal of Political Economy49(5):554-556.

28. Hutchinson, W. K. (2005). Linguistic Distance as a Determinant of Bilateral Trade. Southern Economic Journal 72(1):1-15.

29. Melitz, J. (2008). Language and Foreign Trade. European Economic Review52:667-669.

30. Ku, Hyejin, and Asaf Zussman. (2010). Lingua Franca: The Role of English in International Trade. Journal of Economic Behavior \& Organization75:250-260.

31. Chiswick, B. (1991). Speaking, Reading, and Earnings among Low-Skilled Immigrants. Journal of Labor Economics9(2):149-170.

32. Carnevale, A., R. Fry, and L. Lowell. (2011). Understanding, Speaking, Reading, Writing, and Earnings in the Immigrant Labor Market. American Economic Review91(2):159-163. 